\title{
Lacan's Theory of Desire and Its Practical Value
}

\author{
Wengqiu Wang (Corresponding author) \\ School of General Education \\ Sichuan International Studies University, Chongqing, China \\ E-mail: wangwenqiu@ hotmail.com \\ Yupeng Jia \\ College Translation and Interpreting \\ Sichuan International Studies University, Chongqing, China \\ E-mail: 1183728086a@gmail.com
}

Received: August 30, 2021 Accepted: September 23, 2021 Published: October 11, 2021

doi:10.5296/ijl.v13i5.18970

URL: https://doi.org/10.5296/ijl.v13i5.18970

\begin{abstract}
The word "desire" is one of the core terms in Lacan's psychoanalysis. As the famous saying of Lacan: "the desire of man is the desire of the Others", Lacan's theory of desire is based on Hegel - Koyev's theory of desire. By falsifying the subject, Lacan developed a unique theory of desire, that is, desire is the alienated subject, the fantasy formed in the pursuit of what Freud called the Das Ding which Lacan called the Objet petit A, and finally the fantasy constructs desire retrospectively. The study of Lacan's theory of desire helps to provide more sections for the study of contemporary social phenomena and social development.
\end{abstract}

Keywords: Desire, Objet petit A, Alienation

\section{Alienation of Subject}

Descartes' classic "I think, therefore I am" came out, marking the beginning of human reason to control the world. After the absorption and criticism of Kant and Hegel, the leading figures of German classical philosophy, the subject theory gradually became the core category of western modern philosophy. However, with the development of history, the subject with self-awareness and self-consciousness has been gradually questioned by Philosophers such as Nietzsche, Husserl, and Heidegger. And philosophical schools such as structuralism, deconstruction, Western Marxism, phenomenology, and psychoanalysis have joined the list of subverting or transforming the subject (Chen Rongrong, 2020) And Lacan, just like rewriting 
the relationship between signifier and signified in Saussure, rewrites Descartes' "I think, therefore I am" into "I am thinking where I am not, therefore I am where I am not thinking", sending out a clear clarion call for the charge of subject theory.

Lacan points out that the subject has been transformed into a "false subject" after two brutal alienations, which is also called a divided subject, but the subject is unaware of its situation and thinks that it is still the original self. The subject of alienation began in the mirror stage for the first time, at the time of 6 to 18 months, babies, themselves is in a state of cannot provide for themselves, also can't perceive the outside world, by chance, baby inadvertently exposed to a mirror, and their virtual image in the mirror produced great interest until ecstasy, he cheerfully dancing, look in the mirror-like dancing, Gradually he came to believe that the image in the mirror was himself. However, the baby in the mirror is only an imaginary image, and the baby has an imaginary identity to the image in the mirror but has given up the real self, which means that the subject has been on a road of despair since then, the false subject has been constructed, and the real subject has been strangled. As the baby grows up, he gradually understands how to read and understand the world, and he urgently needs to be recognized by others to satisfy himself. Like Freud for the classic story of his little daughter eat strawberry cake, daughter likes to eat strawberry cake, because Freud's happy to see his daughter eat strawberry cakes, the little daughter sees she eats strawberry cake can let your father happy, so she fell in love with strawberry cake, but she doesn't know whether herself like to eat the cake or not. She took Freud's desires for her own. This also just confirms the famous saying: "The desire of man is the desire of others". It is worth noting that the alienation of the subject in this stage is at the level of the imagination. The subject sees the mirror image of himself from the perspective of others and identifies with it. It is a gaze in which the subject abandons his true self and forms an imaginary, false relationship

After the first alienation, the subject gradually transitions to the symbolic level. When does the subject enter the symbolic realm? Lacan gets answer from Freud. In "Beyond the Pleasure Principle," Freud once told an interesting story: children between the ages of 1 and 2, while their mothers were out, would throw the spool in their hands, pull it back, and send out Fort/Da) The voice. Freud found that this was a game often played by children when their mothers were absent, and believed that the whole game was a symbol of children's "absence and presence" of their mothers, and parodies of children's coping with the reality of frustration. (Wu Qiong, 2011) Lacan called the scene described by Freud the initial moment when the subject enters the symbolic world. At this time, the meaning expressed by children's Fort/Da is not important, but the key is that Fort/Da, a linguistic act, has a symbolic function. Through this ritual of naming the missing thing, the child recreated the mother who was not present. The act of naming, however, can be said to be a metaphorical substitution. The Fort/Da presence of the child comes at the expense of the mother's absence, which is actually a murder of the mother. The very existence of the mother is left behind, and the child can only summon that original loss through the naming ceremony of the mother. In Lacan's view, this is a trap set by the symbolic world or the greater other for the subject. Once entered into this symbolic order, the subject can only be forced to accept the slavery of the greater other. In the imaginary world, the subject constructs a false self by identifying with a virtual image 
in the mirror, but that is not the real subject, it is only an imaginary being. To obtain the identity of the subject, the subject also needs to identify in the symbolic world, and by accepting the order and law of the symbolic world, make himself recognized by the other. From the perspective of psychoanalysis, it means that the Oedipus complex of the subject is forbidden by the symbolic father. Only by confirming and accepting the ban of the "father" can the subject become a social existence, so the subject can only be a castrate subject forever. This is a kind of cruel alienation, "I want to study hard", "I want to be a great writer", "I am the pride of my parents", but "I" is unaware of it, "I" is only a symbol, constantly in the order of the language to accept the call. I am not myself ", the subject gradually accepts his symbol and the call of others, becoming the re-alienation of alienation above nothing. (Chen Rongrong, 2020)

\section{The Generation of Desire}

\subsection{An Explanation of Lacan's Ternary Theory of Need-Demand-Desire}

The subject has been falsified after two experiences of alienation, so the desire issued by the false subject is not the real desire of the subject itself, which leads to Lacan's saying: "the desire of man is the desire of the Others." However, in discussing desire, it is necessary to make a thorough distinction between the three concepts of need, demand, and desire, which Lacan also insists on. For Freud, desire is a kind of sexual drive, an extension of the libido, and this is, of course, a biological statement, which Lacan strongly rejects, because in his view, if the desire is biological, then there is no difference between humans and animals. Therefore, he proposed the ternary relationship of need, demand, and desire. Of the three, necessity is physiological, a purely physiological instinct, one of the conditions of life. For example, when people are thirsty, they need to drink water, and when they are hungry, they need to eat. Once this need is satisfied, there will be a reduction of the need, so the need belongs to specific substances. How does a need become a demand? Lacan, who has always had a special interest in babies, points out that when babies cry, needs become demands. A baby's cry caught the mother's attention, the mother trying to figure out what babies need, baby can't speak at this time, however, mothers have the most common way to comfort their baby - give nipple into crying babies in response to babies need in the mouth, but babies don't need it, instead, they may be sick, maybe need to mother's embrace, and so on, In short, as the other, the mother's needs for the baby do not correspond completely. The original needs of the baby are repressed, and the intervention of language and the other makes the needs become demands. Finally, there is desire. Lacan gives a mathematical formula, which is desire $=$ demand - need. He explains this: When needs are separated from wants, desires take shape at this margin. (Lacan, 2001) Thus it can be concluded that, after the intervention of language, the purely physical needs are removed, and what is left must be something located in the symbolic order, that is, the unconditional love of the other. The other can provide the need of the subject, but it cannot provide the love he demands, because love itself is a lack. Now we can make a simple summary of this ternary relationship: In short, needs are animal appeals. Demands often appear metaphorically or metonymy, that is, when A is asked for, it actually refers to B; Desire is a strong lust for something, that is, a strong desire to get something, but I do not know why I want it (Zhao Chun, 2020). 


\subsection{Causes of Desire}

Desire is born out of demand, but the question remains unresolved: why does the subject want desire? What drives the subject to pursue desire? Lacan called the cause of desire Objet petit A. Lacan called the object A his greatest discovery, claiming: "Marx invented surplus value. I found Objet petit A." This shows the position of the object a in Lacan's philosophical system. Lacan assumes that when the subject enters the symbolic world, to comply with the rules of the symbolic order, the subject is forced to give up his love and leave something outside the gate of the symbolic world. This unsymbolized material is the Objet petit A. In short, the Objet petit $\mathrm{A}$ is the residual product of the failure of the subject in the symbolization process, and it is an unspeakable mysterious object. In his book The Cultural Logic of Psychoanalysis, Zhao Chun gives a very pictorial example: Imagine a dark space where there is a strong light source. From this source, desire cast their light and shadow into the darkness, such as houses, cars, fame, status, etc., but the light source itself is always hidden in the depths of the darkness, can never be seen, we can only catch the shadow cast, but cannot catch the source. (Zhao Chun, 2020) The intense light source is the Objet petit A. Here, the author would like to use a famous saying of Saint Augustine about God: If God is ineffable, according to this argument, God cannot be called ineffable, because when he speaks this sentence, God has already been spoken. (Ellis John M, 1974). In the fable of the Fisherman and His Wife, the fisherman and his wife set free the flounder that had been the prince and kept demanding from him. The fisherman's wife asked for a beautiful house, but her desire has not been fulfilled, she asked for a palace, not enough for her, till the end when she asked to be the Pope, she still didn't feel satisfied. That is because she just captured the Objet petit A's projection on the wall of light, Objet petit A is not being captured, "it" (Objet petit A )changes a new direction, reflecting the light of the other, It draws the subject to the next desire, to infinity.

\subsection{Desire and Fantasy}

Lacan distinguishes desire and need from demand, which is the first identification of desire. The further determination of desire is in the field of Fantasy, where desire enters the room and begins to perform. Lacan gives a famous formula for Fantasy: $\$ \triangleright \mathrm{a}$, read as the desire of the divided subject to the Objet petit A. Fantasy is not a desire, but a stage, or field, for the desire and the elements of desire to present themselves. Žižek, the Slovenian philosopher who read Lacan the best, pointed out that Fantasy tells us what we are to other people. (Žižek, 2006) That is meant to say, Fantasy is a field about the relationship between the subject and others. In this field, different individuals have different cultural backgrounds and different experiential structures, but they are finally integrated into the Fantasy. So, what brings them together? The answer is desire.

"Fantasy, or ghostly configurations, are a response to the enigmatic question of 'che vuoi?'" Writes Žižek in the Plague of Fantasy. (Zhao Chun, 2020) "che vuoi" is the content of Lacan's desire diagram iii. Without further elaboration here, we only need to know one message from Žižek, that is, the subject in the Fantasy plans his own desires according to the desires of others. In the familiar example of Freud's little girl eats cake, the little girl wants to 
eat strawberry cake, but the core is not how to get the piece of strawberry cake $t$, but why the little girl wants to eat that piece of strawberry cake. How is desire transmitted to the young daughter? We now know that the young daughter plans and constructs her desires according to her parents' desires, and the place where the desires are constructed is in the fantasy. The young daughter sees that eating the strawberry cake can make her parents satisfied and approve of her, so the fantasy of the young daughter eating the strawberry cake in front of Freud is constructed based on Freud's desire. Now, in this fantasy, the little girl becomes the object of Freud's desire, and through the intermediary of the cake, the desire is exchanged between Freud and the little girl. Through the interaction of desires between subjects. Fantasy reveals to us what we really are to others.

Based on the above, we can say that the Fantasy provides the subject with the material from the other to construct the desire, and without the Fantasy, the desire would be exhausted, and the Fantasy also serves to maintain the desire. As we know, through Objet petit A and the Fantasy is the desire of the subject, only the body of the division of Objet petit A leads a desire, the body is not a complete body after two alienation, so the body will produce desire to force to give up something, and the desire for Objet petit A constitutes the Fantasy, thus forming a paradox: The desire formed by Fantasy is for the subject to chase the Objet petit A and return the subject to the perfection of the real world, but in order to maintain the endless flow of desire, the subject must remain divided, so as to chase the Objet petit A and form the desire. In this regard, Žižek explained that Fantasy, as a defense mechanism, is to prevent the subject from getting too close to the Objet petit $\mathrm{A}$, which causes disastrous consequences. It acts as a barrier between the symbolic and the real, to prevent the subject from being crushed by the Real. Hence the saying: Desire itself is the resistance to desire(Žižek 2002)

\subsection{Annihilation of Desire}

The fantasy acts as a barrier, preventing the subject from truly grasping the source of the desire, the Objet petit A. The Objet petit A must keep a certain distance from the subject so that the desire can operate normally. If the subject catches the Objet petit A, it means the annihilation of the desire. Here we can use Mary Shelley's classic novel Frankstein to explain the annihilation of desire. In Frankstein, the protagonist victor, because he was unable to suppress the Oedipus complex, in his study, he was trying to resurrect the mother, by his own strength at this time, for mother's obsession became the object of victor's Objet petit A, driving the victor to complete his terrible invention, even amid a symbol of world ethics and legal norms, Victor still finished his invention. However, when his invention was completed, Victor was terrified: Ah! No one on earth could bear the horror of his image! Even if the mummy is resurrected, he is not so ferocious! ... I was in agony that night, and my pulse was so swift and violent that at times it seemed every vein was throbbing. Sometimes I almost collapsed from exhaustion and exhaustion. Mixed with the horror was the bitterness of disappointment. The dream that had long been my source of nourishment and joy had now become my hell. How quickly that change comes! How thoroughly I was turned upside down! (Mary Shelley, 2018) through the victor itself by the desire to build fantasy, that should exist in the real dead mother. However, when Victor resurrects his "mother" and embraces the Objet petit A, he did not get the imagined satisfaction, but panic, eventually the rest of his life 
must bear the guilt and shame until he and the monster he created die together. From the perspective of psychoanalysis, the behavior logic of the novel is that the mother in the Real is reborn in the fantasy through the desire for the Objet petit A, while Victor insists on passing through the fantasy and giving the Objet petit A a directive gaze. Finally, the fantasy is broken, the desire is annihilated, and everything disappears into air.

\section{Realistic Value of Desire Theory}

Lacan's theory of desire has a profound influence, and it can help us to think more deeply about the problems we encounter in the development of contemporary society. Some scholars once commented that today's society is a materialistic society, which has become a home of desire and a veritable vanity fair. In this vanity fair, the rapid expansion of desire, the original need is alienated into desire, and eventually makes people lost in the desire. Jean Baudrillard, the French master of postmodernism, deeply revealed the nature of this society, that is, the society is divided into a consumer society and a symbol society. The original objects are divided into two levels, one is the real existence representing the actual needs, and the other is the symbolic needs. Therefore, consumption in Marx's relations of production is alienated, people's real needs are covered by symbolic needs, and some are endless but unsatisfied desires. In Baudrillard's view, in today's society, people pay more and more attention to the symbolic value of objects, while the functionality of objects is gradually melting, and the process of symbolic consumption of objects represents the process of subjects chasing down the differences in social status. As Lacan that famous words say "the desire of man is the desire of the Others ", under the Other's words, the main body to obtain the recognition of the Other, will be desperate to Other, for example, a woman bought the latest Hermes handbag, because Hermes handbags mean gentry standard, this is essential for the woman who eagers to enter upper-class. Whether to enter society is determined by the Other, when the Hermes standard on the significance of the brand as the upper class gives in that bag, the woman has made their own desire of material, also means that if the other people also think Hermes handbag is the upper-class standard, the woman will agree with this view. Moreover, they regard Hermes handbags as their object of desire. Therefore, woman's consumption of Hermes handbags is to pay for the symbolic value needed to enter the upper class, and such consumption of symbols makes the subject acquire a sense of existence. In this way, it can be said that the symbolic consumption of things contributes to the generation of desire, which drives the subject to pursue the false identification, as if the symbolic value of commodities is the value of their own existence.

In a consumer society, people seek differences by consuming symbols of different levels, build their own identity and status in the society, and regard differentiated consumption as their goal. The difference is fleeting, however, as the source of light in the dark, the differences between the move as the light source, also in constant change, like constantly updated iPhone and various series cars, subject to obtain difference disappeared soon after in innovation, to get the difference, consumption also unavoidable, Only through consumption can we obtain a real sense of existence and peace, and this constant self-consumption eventually makes the subject completely lost in the self-created consumption desire trap, and makes the whole society fall into a pathological consumption cycle. It can be concluded that 


\section{Macrothink}

International Journal of Linguistics

ISSN 1948-5425

2021, Vol. 13, No. 5

the alienation of consumption dissolves the real need and generates the desire, while the constant pursuit of difference makes the subject become the slave of the desire of the other, which is driven and unable to extricate itself.

\section{Conclusion}

Ever since Lacan's theory of desire was born, critics have criticized it as historicism; The supremacy of the signifier is too absolute; An excessive belief in nothingness, and so on. However, it has to be said that Lacan's theory of desire has well explained a series of social phenomena. As society's obsession and superstition with certain brands have reached the point where people don't buy them, we can deeply realize that social desire is rapidly expanding. However, Lacan's theory of desire undoubtedly gives us a blow of wakefulness, which makes us keep sober cognition and vigilance of our desires, and keep in mind the control and balance of our desires, to realize self-liberation and all-round development of human beings.

\section{References}

Chen, R.-R. (2020). The analysis of Lacan's desire theory and the contemporary value. Journal of Chongqing University of Technology (Social Science), 149-155

Ellis, J. M. (1974). The theory of literary criticism. University of California Press.

Lacan. (2001). Ecrits. Routledge: Great Britain, p. 156.

Shelley, M. (1960). Frankstein. New York: Dent \& Dutton, pp. 65-68.

Wu, Q. (2011) Jacques Lacan: Read your symptoms. China Renmin University Press, p. 62.

Zhao, C. (2020). Cultural logic of psychoanalysis. Science Press, pp. 38-39.

ŽižekSlavoj. (2002). The Sublime Object of Ideology. Central Compilation \& Translation Press, p. 24.

ŽižekSlavoj. (2006). How to read Lacan. London: Granta, p. 89.

\section{Copyrights}

Copyright for this article is retained by the author(s), with first publication rights granted to the journal.

This is an open-access article distributed under the terms and conditions of the Creative Commons Attribution license (http://creativecommons.org/licenses/by/4.0/) 